\title{
Did the COVID-19 Lockdown-Induced Hydrological Residence Time Intensify the Primary Productivity in Lakes? Observational Results Based on Satellite Remote Sensing
}

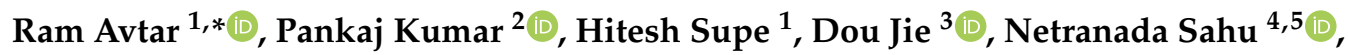 \\ Binaya Kumar Mishra ${ }^{6}$ and Ali P. Yunus ${ }^{7,8}$ (i) \\ 1 Faculty of Environmental Earth Science, Hokkaido University, Sapporo 060-0810, Japan; \\ hiteshsupe@eis.hokudai.ac.jp \\ 2 Natural Resources and Ecosystem Services, Institute for Global Environmental Strategies, Hayama, \\ Kanagawa 240-0115, Japan; kumar@iges.or.jp \\ 3 Department of Civil and Environmental Engineering, Nagaoka University of Technology, Kami-Tomioka, \\ Nagaoka 1603-1, Japan; douj888@gmail.com \\ 4 Department of Geography, Delhi School of Economics, University of Delhi, New Delhi 110007, India; \\ nsahu@geography.du.ac.in \\ 5 Disaster Prevention Research Institute, Kyoto University, Kyoto 611-0011, Japan \\ 6 School of Engineering, Pokhara University, Lekhnath 22700, Nepal; bkmishra@pu.edu.np \\ 7 State Key Laboratory for Geohazard Prevention and Geoenvironment Protection, \\ Chengdu University of Technology, Chengdu, Sichuan 610059, China; pulpadan.yunusali@nies.go.jp \\ 8 Center for Climate Change Adaptation, National Institute for Environmental Studies, Tsukuba, \\ Ibaraki 305-8056, Japan \\ * Correspondence: ram@ees.hokudai.ac.jp; Tel.: +81-011-706-2261
}

Received: 6 August 2020; Accepted: 10 September 2020; Published: 15 September 2020

\begin{abstract}
The novel coronavirus pandemic (COVID-19) has brought countries around the world to a standstill in the early part of 2020. Several nations and territories around the world insisted their population stay indoors for practicing social distance in order to avoid infecting the disease. Consequently, industrial activities, businesses, and all modes of traveling have halted. On the other hand, the pollution level decreased 'temporarily' in our living environment. As fewer pollutants are supplied in to the hydrosphere, and human recreational activities are stopped completely during the lockdown period, we hypothesize that the hydrological residence time (HRT) has increased in the semi-enclosed or closed lake bodies, which can in turn increase the primary productivity. To validate our hypothesis, and to understand the effect of lockdown on primary productivity in aquatic systems, we quantitatively estimated the chlorophyll-a (Chl-a) concentrations in different lake bodies using established Chl-a retrieval algorithm. The Chl-a monitored using Landsat- 8 and Sentinel-2 sensor in the lake bodies of Wuhan, China, showed an elevated concentration of Chl-a. In contrast, no significant changes in Chl-a are observed for Vembanad Lake in India. Further analysis of different geo-environments is necessary to validate the hypothesis.
\end{abstract}

Keywords: hydrological residence time (HRT); lake; COVID; waterbodies

\section{Introduction}

The residence time is a fundamental descriptor in hydrology that provides information on the timescales of a molecule of water spend in a specific system. Hydrological residence time (HRT) is estimated as the amount of time the water spent in any section of the connected network [1]. 
The longer a parcel of water remains in a specific system (river, lake, ponds, etc.), the longer is its residence time, and vice versa. HRT has got important applications in a wide range of hydrological fields including water quality analysis, stratification, habitat ecology, age dating, water mixing and circulation, microbiological contaminants, etc., [2-4]. For example, Zwart et al. [4] showed that lakes with short HRT had higher dissolved organic carbon and greater net heterotrophy. Hein et al. [5] and others noticed that a prolonged residence time increases the primary productivity in aquatic systems. Similar observations have been noticed in several other works. For instance, León et al. [6] reported that chlorophyll-a was directly related to the HRT. Stumpner et al. [7] showed that zones of longer HRT (15-60 days) have higher Chl- $a$ concentrations, and ones of shorter HRT (1-14 days) have lower Chl-a concentrations.

The SARS-CoV-2, or popularly the Coronavirus Disease 2019 (COVID-19) that affected the world population in early 2020, caused several nations and territories to a stand-still. Over 25 million infected persons and more than 860,000 deaths have been reported worldwide caused by the COVID-19 as of 1 September 2020 [8]. Since no vaccine or cure has developed to protect the body against the COVID-19, complete or partial lockdown has been induced in many countries and territories to stop the chain of infection. As vehicular movement halts, construction is put on hold, and industries stop production, the levels of pollution level has come down both in atmosphere and hydrosphere $[9,10]$.

The industrial sewage input to the lakes through inlets, recreational activities in lakes such as boating, fishing, etc., stopped temporarily in aquatic systems during COVID-19-induced lockdown. We hypothesize that the hydrological residence time in closed or semi-enclosed lakes has increased, which may, in turn, increase the primary productivity. To validate our hypothesis and to understand the effect of lockdown on primary productivity in aquatic systems, this study explores to quantify the level of Chl- $a$ before and during the lockdown period using remote sensing techniques. Chl- $a$ derived from OC3 algorithm [11] is selected for comparing the eutrophication status before and during the lockdown.

While, the hydrological residence time is not the only factor that influence the primary productivity, other factors such as temperature, increased light exposure, oxygen level, initial nutrients levels, etc., also could cause an increase or decrease in the level of Chl- $a$ concentration in the aquatic environments [12-14]. For instance, Castelao et al. [15] using geostationary satellite data showed the seasonal development of coastal upwelling in which the maximum was peaked in the summer and minimum during the winter. In oligotrophic waters, maximum phytoplankton production often occurs near the top of a nutricline [16]. In addition, in inland water bodies the intensity of monsoon rainfall and landscape heterogeneity tremendously influenced the Chl- $a$ concentrations [17]. Further, in places of upwelling areas, the water surface temperatures are often cooler than nearby waters, resulting in an increased chlorophyll concentration. However, we assume in this study that the boundary conditions remain unchanged during the observation period for both the study areas and, hence, examined the effect of HRT on water quality.

\section{Study Area}

The stringent and biggest of all lockdown was imposed in two places, (i) Wuhan, China, the epicenter of COVID-19, and (ii) India, where 1.3 billion people have been staying home since 25 March 2020. Hence, we selected some lake bodies in Wuhan city (Figure 1a) and one lake body in India (Vembanad Lake, the longest freshwater lake in India) (Figure 1b). These lake bodies are also preferred because of the availability of cloud-free remote sensing images, and expected longer HRT caused by the stringent lockdown in these areas. Both the selected cases experienced severe pollution by wastewater disposal, industrial effluents, heavy metal concentration, and micro-plastics before the lockdown $[18,19]$. 


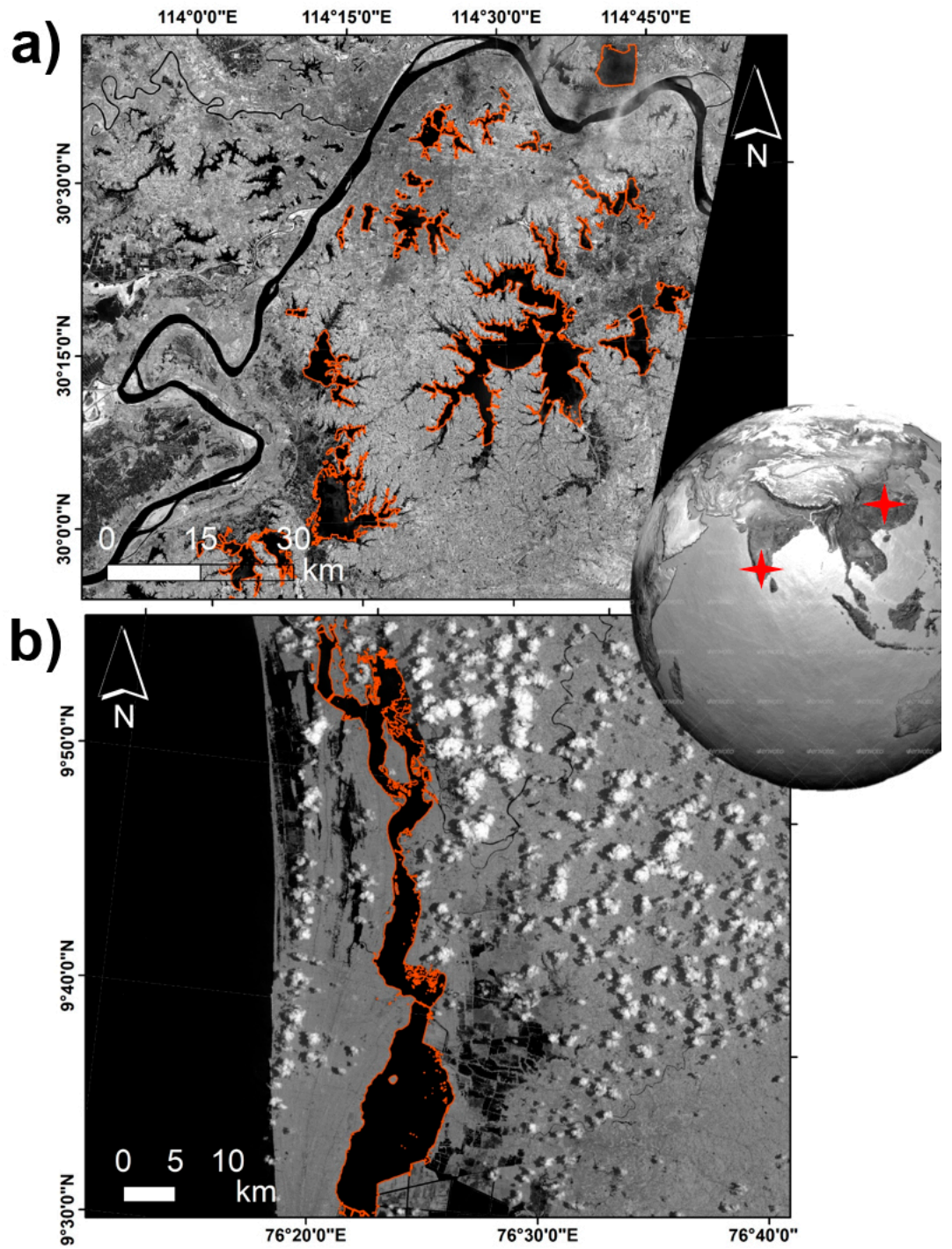

Figure 1. Location of the study area (a) lakes of Wuhan, China, and (b) Vembanad Lake, India.

\section{Data and Methodology}

\subsection{Theoretical Framework}

The amount of water spent in any section of the water body is an important consideration for many water quality problems [1]. In general, the regions near the inlet are having less residence time than the far places. Further, in a closed water body or semi-closed lakes, the movement of water is largely constrained, therefore having longer residence time. Dickman, [20] showed that increased water residence time more likely increases the algae bloom, especially for small reservoirs. Several other works showed that Chl- $a$ increases with increasing residence time and decreases with increasing discharge [21,22]. The hydrological residence time in our study area was expected to increase during the lockdown period owing to following reasons: (i) sewage disposal to the lakes has completely stopped, causing reduced discharge via inlets, and (ii) all anthropogenic activities, including boating has stopped during the lockdown period, causing still waters. The lockdown induced by COVID-19 in this ecosystem with a long retention time, thus offering an opportunity to study the development of phytoplankton that are otherwise adapted to a turbid environment.

While HRT has been traditionally measured through dye-tracer experiments in the field or estimating the ratio of the volume of the domain of interest to an outgoing flux [23]. Recently, 
physically based hydrodynamic modeling is employed to estimate the residence [24]. In this study, we assumed that the HRT is the longest during the lockdown period.

\subsection{Image Acquisition and Data Processing}

Landsat 8 OLI images and Sentinel-2 images of the immediate pre-lockdown period (December 2019 and January 2020) and during the lockdown period (February-April 2020) were downloaded (Table 1) from the United States Geological Survey (USGS) website (earthexplorer.usgs.gov). All scenes had undergone terrain correction within prescribed tolerances. Table 1 shows the details of satellite images used in this study for Chl- $a$ mapping. The Level 1 Landsat- 8 and Sentinel- 2 images were further treated using ACOLITE software for radiometric calibration (Top of Atmosphere Reflectance) and atmospheric correction (Surface Reflectance). ACOLITE, developed by Royal Belgian Institute of Natural Science, employs a "dark spectrum fitting" (DSF) approach $[25,26]$ for atmospheric correction. For detailed procedure on atmospheric correction for Landsat-8 OLI in an ACOLITE environment, readers are referred to the following references $[27,28]$. For validation purpose, we used the satellite images of 2017-2019 March-April images. The validation dataset was directly used in Google Earth Engine (GEE) platform with the help of chlorophyll index algorithm [14]. The GEE codes are provided in the Supplementary File S1.

The variability in the meteorological conditions during the study period may affect the chlorophyll concentrations. While the regional air temperatures were increasing from December to April by about $10^{\circ}$ Celsius for Wuhan, the average temperature difference was only about $2^{\circ}$ Celsius for Vembanad region (source: https://www.timeanddate.com). The precipitation condition was normal for both case areas with occasional rainy days observed during the study period (Figure 2).
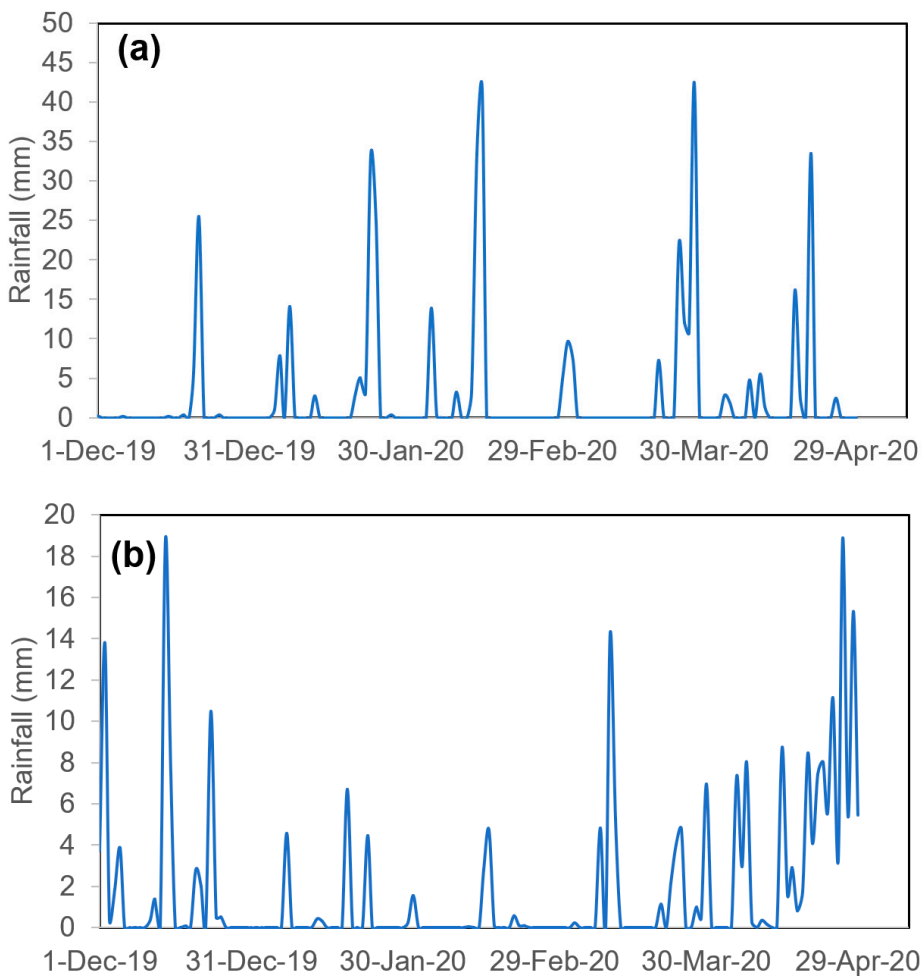

Figure 2. Daily precipitation (mm) time series chart for (a) Wuhan and (b) Vembanad (Cochin) during the study period (source: CHIRPS Daily: Climate Hazards Group InfraRed Precipitation with Station Data (version 2.0)). 
Table 1. Details of the satellite images used for mapping chlorophyll- $a$ (Chl- $a$ ) before and during the lockdown period in 2020 .

\begin{tabular}{|c|c|c|}
\hline S. No & Wuhan Lakes & Vembanad Lake \\
\hline 1 & $\begin{array}{l}\text { ID: } \\
\text { LC08_L1TP_123039_20191207_20191217_01_T1 } \\
\text { Acquisition Date: 2019-12-07, Path: 123 Row: } 39\end{array}$ & $\begin{array}{l}\text { ID: LC08_L1TP_144053_20200228_20200313_01_T1 } \\
\text { Acquisition Date: 2020-02-28, Path: 144, Row: } 53\end{array}$ \\
\hline 2 & $\begin{array}{l}\text { ID: L1C_T50RKU_A023910_20200120T030612 } \\
\text { Acquisition Date: 2020/01/20, Tile Number: } \\
\text { T50RKU }\end{array}$ & $\begin{array}{l}\text { ID: LC08_L1TP_144053_20200315_20200325_01_T1 } \\
\text { Acquisition Date: 2020-03-15 }\end{array}$ \\
\hline 3 & $\begin{array}{l}\text { ID: L1C_T50RKU_A024053_20200130T030534 } \\
\text { Acquisition Date: 2020/01/30 }\end{array}$ & $\begin{array}{l}\text { ID: LC08_L1TP_144053_20200331_20200410_01_T1 } \\
\text { Acquisition Date: 2020-03-31 }\end{array}$ \\
\hline 4 & $\begin{array}{l}\text { ID: } \\
\text { LC08_L1TP_123039_20200209_20200211_01_T1 } \\
\text { Acquisition Date: 2020-02-09 }\end{array}$ & $\begin{array}{l}\text { ID: L1C_T43PFL_A024755_20200319T051246 } \\
\text { Acquisition Date: 2020/03/19, Tile Number: T43PFL }\end{array}$ \\
\hline 5 & $\begin{array}{l}\text { ID: L1C_T50RKU_A015788_20200315T030729 } \\
\text { Acquisition Date: 2020/03/15 }\end{array}$ & $\begin{array}{l}\text { ID: L1C_T43PFL_A015918_20200324T052110 } \\
\text { Acquisition Date: 2020/03/24 }\end{array}$ \\
\hline 6 & $\begin{array}{l}\text { ID: L1C_T50RKU_A024768_20200320T030130 } \\
\text { Acquisition Date: 2020/03/20 }\end{array}$ & $\begin{array}{l}\text { D: LC08_L1TP_144053_20200331_20200410_01_T1 } \\
\text { Acquisition Date: 2020-03-31 }\end{array}$ \\
\hline 7 & $\begin{array}{l}\text { ID: L1C_T50RKU_A025054_20200409T030244 } \\
\text { Acquisition Date: 2020/04/09 }\end{array}$ & $\begin{array}{l}\text { ID: L1C_T43PFL_A016061_20200403T052351 } \\
\text { Acquisition Date: 2020/04/03 }\end{array}$ \\
\hline 8 & $\begin{array}{l}\text { ID: } \\
\text { LC08_L1TP_123039_20200413_20200422_01_T1 } \\
\text { Acquisition Date: 2020-04-13 }\end{array}$ & $\begin{array}{l}\text { ID: LC08_L1TP_144053_20200416_20200423_01_T1 } \\
\text { Acquisition Date: 2020-04-16 }\end{array}$ \\
\hline 9 & $\begin{array}{l}\text { ID: L1C_T50RKU_A025340_20200429T030455 } \\
\text { Acquisition Date: 2020/04/29 }\end{array}$ & \\
\hline 10 & $\begin{array}{l}\text { ID: } \\
\text { LC08_L1TP_123039_20200429_20200509_01_T1 } \\
\text { Acquisition Date: 2020-04-29 }\end{array}$ & \\
\hline
\end{tabular}

\subsection{Chlorophyll-a Retrieval}

The reflectance ratio of blue and green wavelengths in the electromagnetic spectrum was recognized to correlate well with the distribution of chlorophyll in surface waters [29-31]. Several studies have supported the usage of blue-green bands on the assumption that any changes in these wavelengths are driven by changes in phytoplankton concentrations [32,33]. The performance of blue-green ratioed algorithms for retrieving Chl- $a$ was tested independently in different environments [34-38]. We, therefore, employed the OC3 algorithm [11], which uses the water leaving reflectance $\left(\mathrm{R}_{\mathrm{rs}}\right)$ in wavelength 443, 482, and 561 for Landsat 8 (Equations (1)-(4)), and 490 and 560 for Sentinel 2 sensor (Equations (1)-(3), and (5)). Mathematically, OC3 Chl- $a$ algorithm is expressed as:

$$
\begin{gathered}
\text { Chl } l_{O C 3}=10^{y} \\
y=a_{0}+a_{1} x+a_{2} x^{2}+a_{3} x^{3}+a_{4} x^{4} \\
x=\log _{10}(R) \\
R=\frac{\max \left(R_{r s}(443,482)\right)}{R_{r s} 561} \\
R=\frac{R_{r s} 490}{R_{r s} 560}
\end{gathered}
$$

The coefficients $0.2412,-2.0546,1.1776,-0.5538,-0.4570$ are, respectively, used for $a_{0}$ to $a_{4}$ (https://oceancolor.gsfc.nasa.gov/atbd/chlor_a/). The performance evaluation of Chl- $a$ retrievals using Sentinel-2 data and OCx algorithms based on Acolite was found within the root mean squared 
logarithmic error (RMSLE) of 1.2-1.3 [39]. In another study, by employing OC3 algorithm for Indonesian seas, the RMSE of in situ vs. satellite Chl- $a$ was found within the range of 0.04-0.05 [40], suggesting superior performance of satellite retrievals of Chl- $a$ in aquatic systems.

\section{Results and Discussion}

\subsection{Lakes in Wuhan}

Figures 3 and 4a presents the Chl- $a$ concentration maps of lakes in Wuhan for pre-lockdown (7 December 2019; 20 January 2020), during the lockdown (30 January 2020; 9 February 2020; 15 and 20 March 2020) and post-lockdown periods (9, 13 and 29 April 2020). It can be seen that the mean Chl- $a$ concentrations were very low in the pre-lockdown period $(2.77$ and $2.95 \mu \mathrm{g} / \mathrm{L})$ and immediately after the lockdown period $(2.25 \mu \mathrm{g} / \mathrm{L})$. By 9 February, the mean concentration gradually increased to $3.05 \mu \mathrm{g} / \mathrm{L}$. Note that the lockdown was imposed on 23 January in Wuhan. The peak Chl-a was observed in the March months (6.57 and $5.88 \mu \mathrm{g} / \mathrm{L}$ ), which also corresponds to the peak period of the quarantine period in Wuhan. The lockdown ended on April 8; the mean Chl- $a$ for April shows a gradually decreasing trend $(5.06,4.49$, and $4.74 \mu \mathrm{g} / \mathrm{L})$.

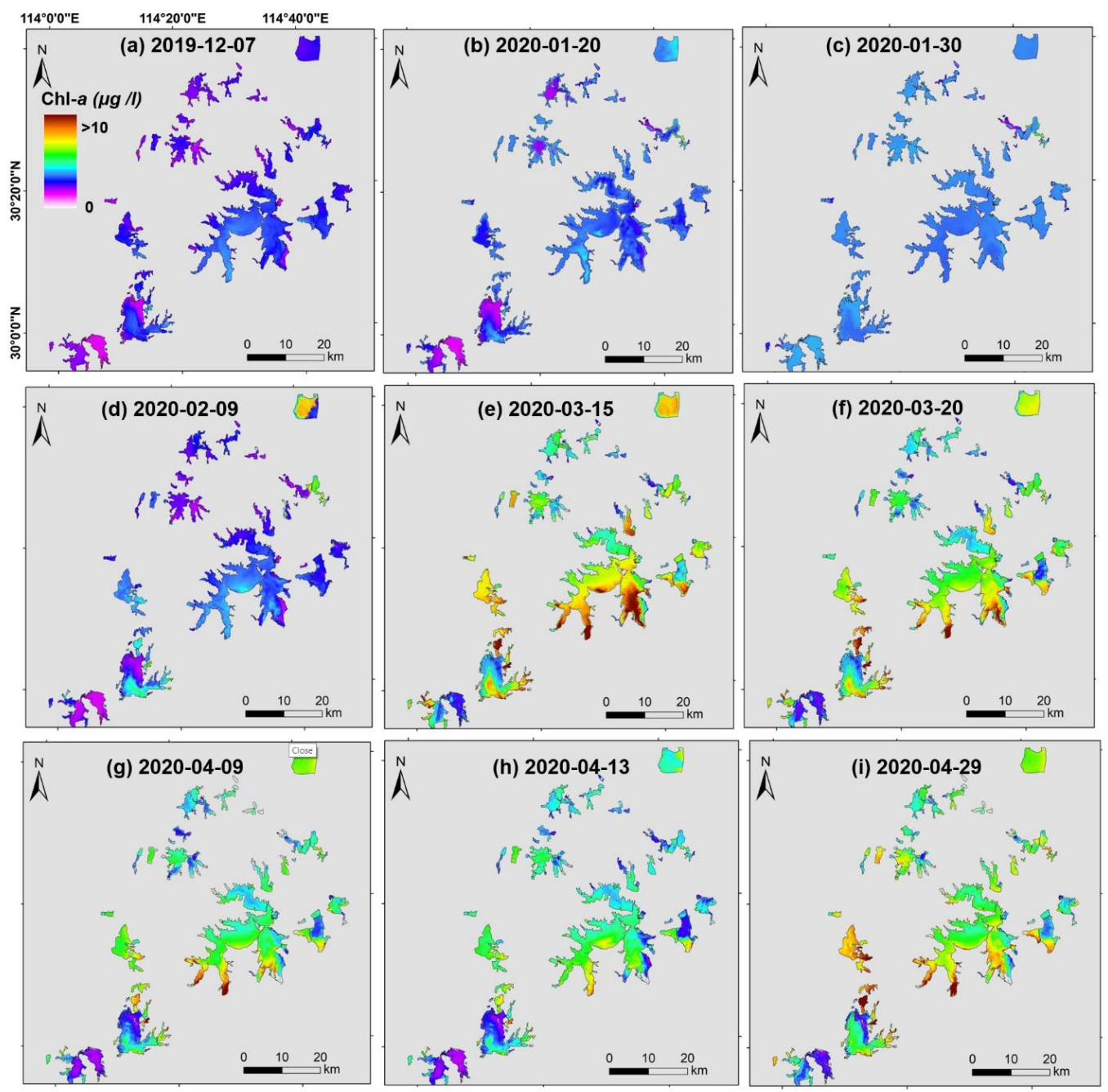

Figure 3. Chlorophyll- $a$ concentration before, during, and post the lockdown period estimated using OC3 algorithm for Wuhan scenic lakes. 

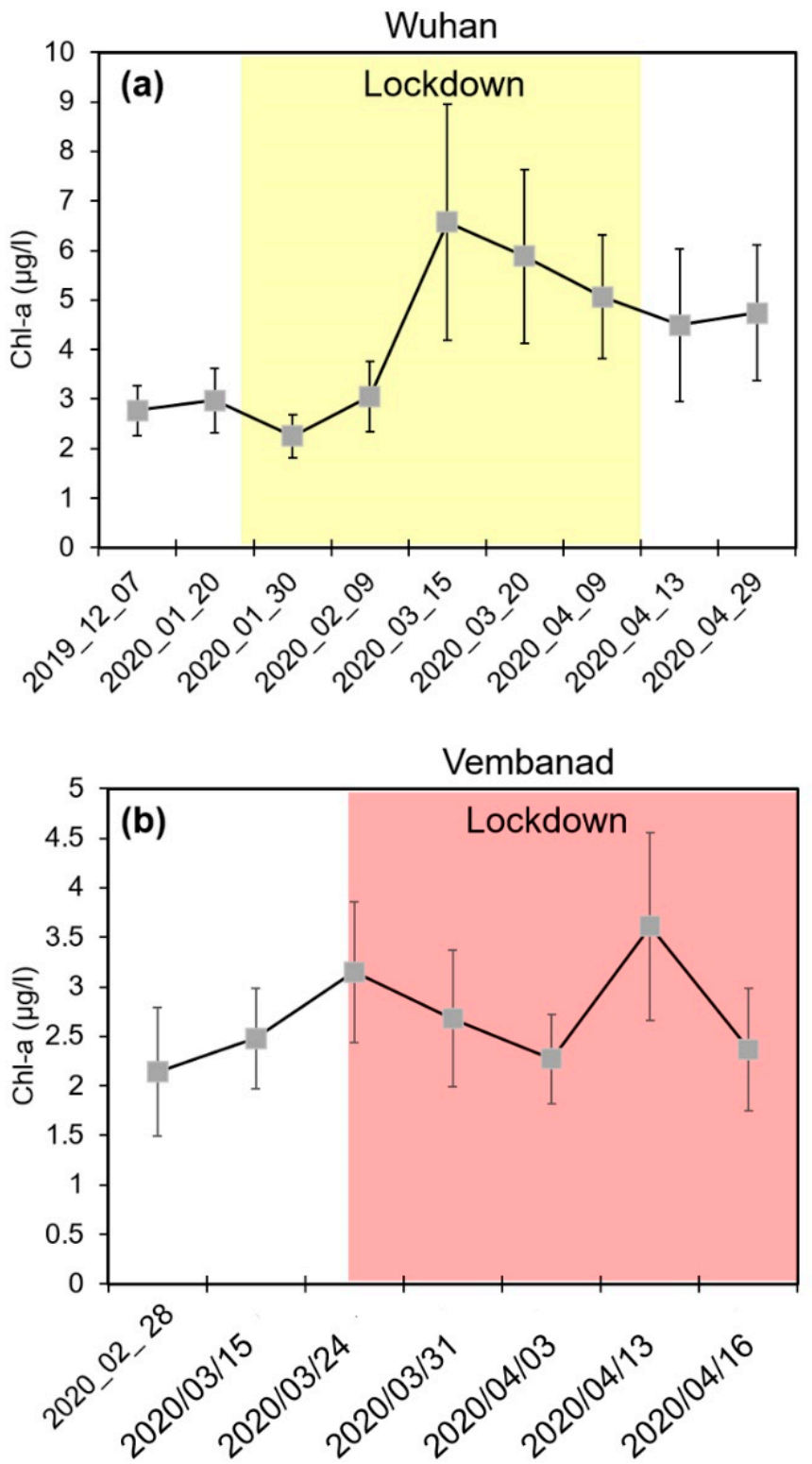

Figure 4. Mean chlorophyll- $a$ during pre, during, and post lockdown in (a) Wuhan Lake and (b) Vembanad Lake (error bar shows \pm standard deviations).

\subsection{Vembanad Lake, India}

Figures $4 \mathrm{~b}$ and 5 present the results of Chl- $a$ concentration before (28 February 2020; 15 March 2020; 24 March 2020) and during the lockdown period (31 March 2020; 4 April 2013; 13 April 2013; 16 April 2020). Note that the lockdown started on 25 February in India and was still ongoing during the study period. Contrary to the former analyzed area, Lake Vembanad does not show any significant increase in primary productivity during the lockdown period. Nevertheless, the concentration was not decreased during this period (Figure 4b). 

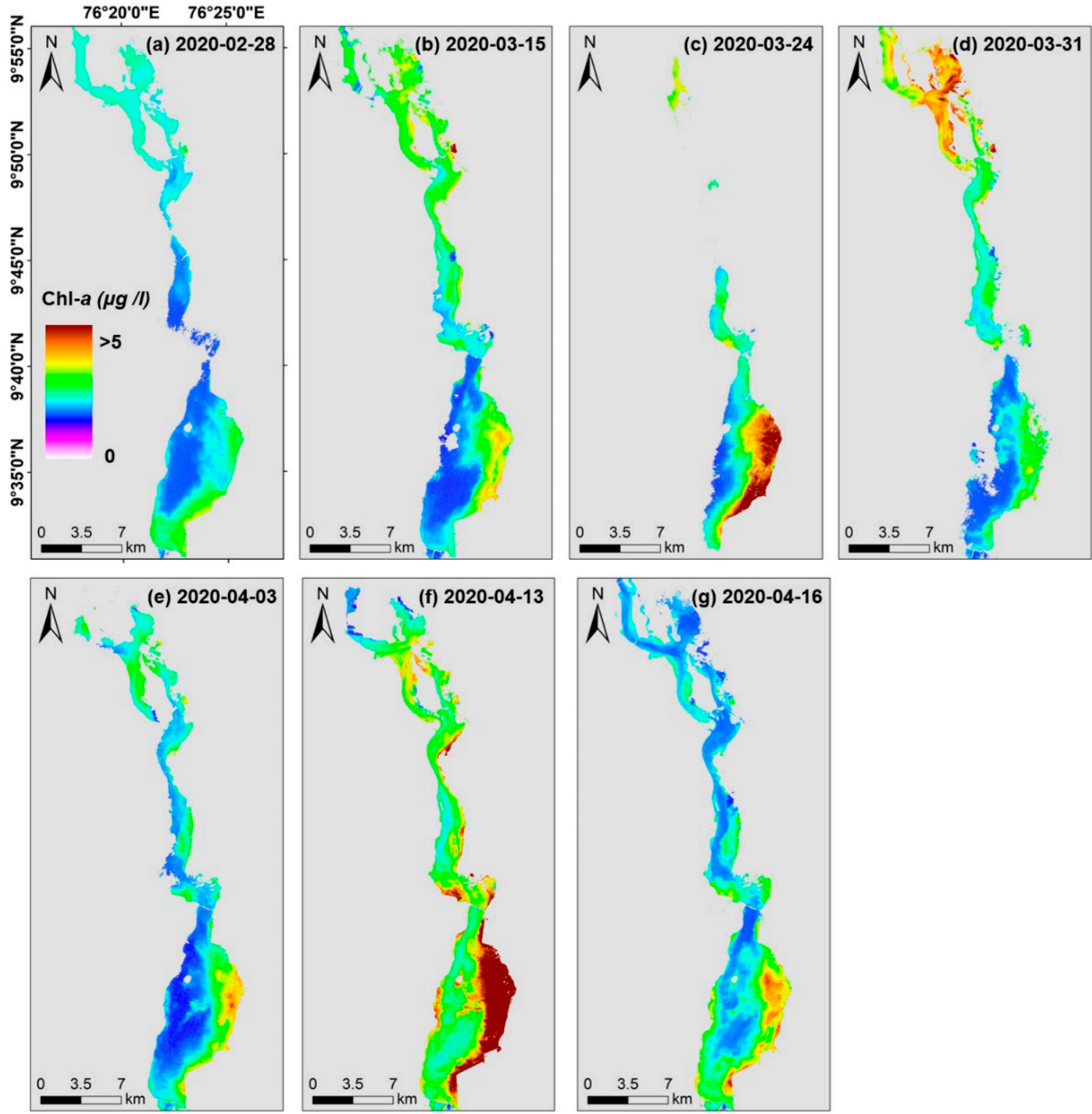

Figure 5. Chlorophyll- $a$ concentrations before and during the lockdown period estimated using OC3 algorithm for Vembanad Lake waters.

\subsection{Validation}

Since there is an $\sim 10^{\circ}$ celcius increase in temperature from December to April in Wuhan climatology, it is expected that the Chl- $a$ also increased during this time period. In order to validate the hypothesis that the increased Chl- $a$ in the lakes of Wuhan during the lockdown period in 2020 is because of the increased HRT, we monitored the Chl-a for the previous years $(2017,2018$, and 2019) during the same time period. The comparative maps of mean Chl- $a$ for 2020 (March-April) and those of previous years (2017-2019) during the same time period are presented in Figure 6. It can be seen that the Chl-a during 2020 March-April is the maximum among the study years, especially in the lakes far away from the city center. This implies that hydrological residence time was maximum in places where the influence of human activity was minimum and, indeed, strengthen our results presented in Section 4.1. 

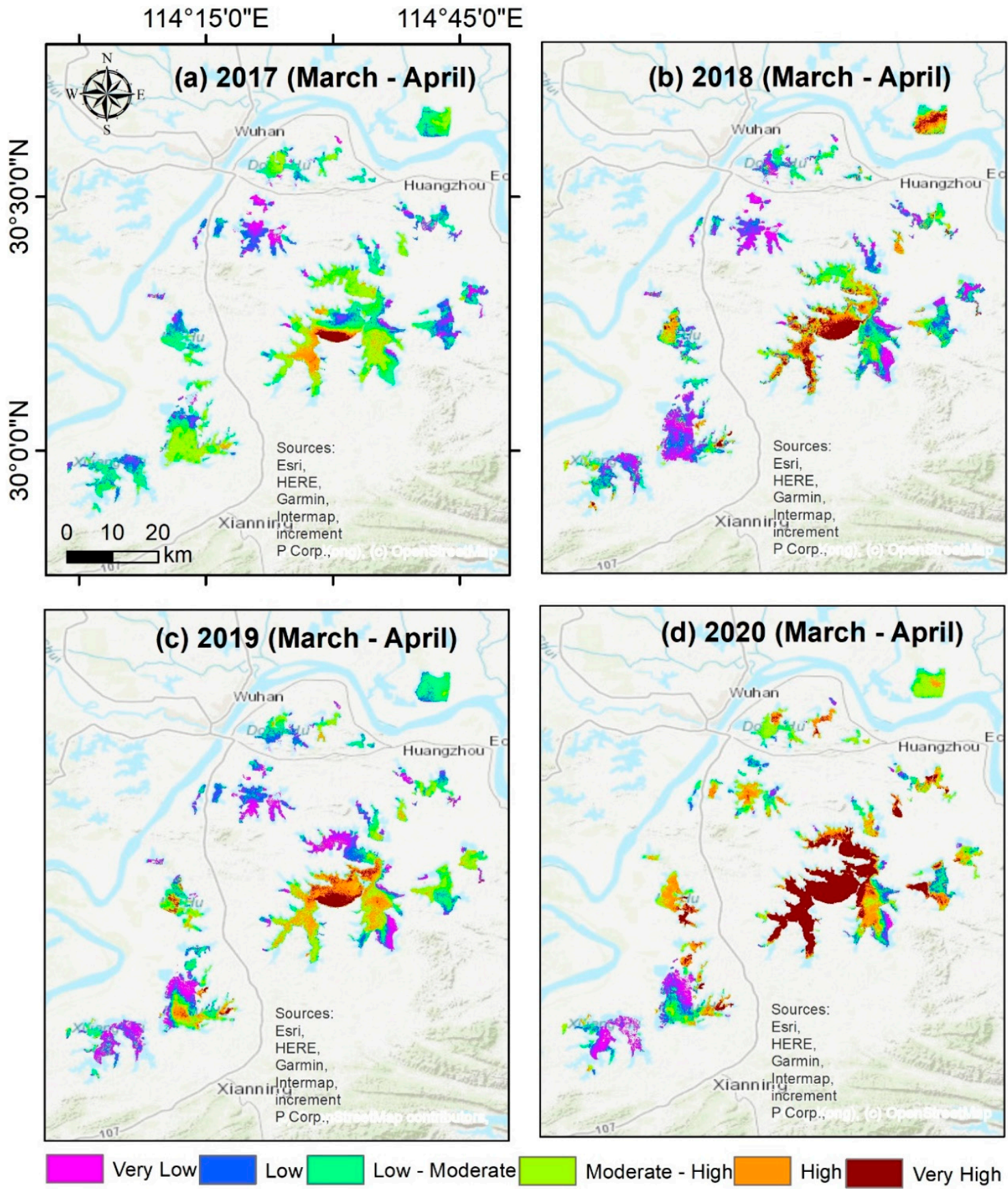

Figure 6. Mean chlorophyll-a concertation mapped for (a) 2017, (b) 2018, (c) 2019, and (d) 2020 during April-May months (for simplicity, the chlorophyll index algorithm [14] is used in Google Earth Engine (GEE) to derive the low to high classes).

\section{Discussion and Concluding Remarks}

As the pollutant discharges into lakes and human activities (boating and fishing) stopped or reduced during the COVID-19 lockdown period, we investigated whether the residence time in lakes also increased in associated with it? We tried to answer the problem mentioned above by analyzing the primary productivity in the lakes. Reynolds, [41], and others reported that increased residence time favors Chl- $a$ and biomass accumulation in aquatic systems [7]. In our study, we noticed an elevated level of Chl- $a$ for the lakes of Wuhan during the initial phase of the lockdown period, followed by a decreasing trend (Figure 4a). This elevated Chl- $a$ indicates an increased HRT in the lakes of Wuhan. 
The decreasing trend followed by the increase may be because a prolonged HRT can settle down the surface phytoplankton [42].

On the other hand, the Vembanad Lake in India does not show any significant changes in Chl- $a$ concentration during the lockdown period. A possible explanation is that the Vembanad Lake is not a closed lake, unlike the lakes in Wuhan. Seven rivers are draining into it, plus it has an opening to the Arabian Sea in the north-west, which carries salt water up to $26 \mathrm{~km}$ inside the lake during the high-tide period. Thus, it may be because the discharge from the rivers (without pollutants) and tidal action cause the HRT to be insufficient for enhancing primary productivity in the Vembanad Lake. It is noteworthy to mention here that both cases, i.e., Wuhan lakes and the Vembanad Lake, have shown a significant decrease in suspended particulate matter during the lockdown period [10] (Supplementary Materials Figures S1 and S2).

One may, though, argue that the increased Chl- $a$ in Wuhan lakes can also be associated with increased water temperature. However, time series Chl- $a$ maps compared for different years (2017-2020) show that the year 2020 experienced the maximum value of chlorophyll in the lakes of Wuhan. This demonstrates that Chl- $a$ concentration during the lockdown has increased in a closed lake system, i.e., for Wuhan, whereas the Chl-a remains unchanged in an open lake system such as the one demonstrated for Vembanad Lake in India. The hydrological residence time induced during the lockdown is by large the influencing factor on increased Chl- $a$, in that it can describe the prolonged residence time increases the primary productivity in closed systems.

The Chl- $a$ retrieval using NASA's OC3 algorithm, however, was not validated in this study with spatiotemporally matched field-derived measurements of chlorophyll because of stringent lockdown measures in both cities. However, the capability of OC3 for Chl- $a$ retrieval in inland lakes and ocean waters in previous studies show a near one-to-one relationship and can be accounted for the Chl- $a$ variability up to upper $10 \mathrm{~m}$ of the water column [43]. In addition, the research framework also does not incorporate the variability of Chl- $a$ caused by other natural phenomena's, and the amount of water contaminant flow into lakes from household wastes, which are usually difficult to model in satellite-based bio-physical parameter estimations. Nevertheless, the methodology and results presented in our study can help in understanding the influence of lockdown on water quality parameters, especially phytoplankton concentrations. Thus, although the research framework can offer important insights into short-term changes in the hydrosphere, additional analysis incorporating time-series data, and similar studies in closed lakes in other climatic environments is necessary to further validate our hypothesis.

Supplementary Materials: The following are available onlsupine at http://www.mdpi.com/2073-4441/12/9/2573/s1, Figure S1: Decreased suspended particulate matter in different lakes of Wuhan during the lockdown period, Figure S2: Decreased suspended particulate matter in Vembanad lake during the lockdown period, Text S1: Codes for chlorophyll index using Sentinel-2 images in GEE.

Author Contributions: Conceptualization: R.A., A.P.Y.; methodology: R.A., A.P.Y.; validation: R.A., A.P.Y.; writing—original draft: R.A., P.K., H.S., D.J., N.S., B.K.M., A.P.Y.; writing—review and editing: R.A., P.K., H.S., D.J., N.S., B.K.M., A.P.Y.; funding acquisition, R.A., A.P.Y. All authors have read and agree to the published version of the manuscript.

Funding: This research received no external funding.

Acknowledgments: Authors would like to thank Hokkaido University L-station and SOUSEI support for Young Researcher. Furthermore, the authors are thankful to the United States Geological Survey (USGS) and Copericus hub for providing satellite data and ACOLITE software provided by RBINS. We also acknowledge the support of Dr. Masago Yoshifumi and appreciate the contribution made by the anonymous reviewers.

Conflicts of Interest: The authors declare no conflict of interest. 


\section{References}

1. Leray, S.; Engdahl, N.B.; Massoudieh, A.; Bresciani, E.; McCallum, J. Residence time distributions for hydrologic systems: Mechanistic foundations and steady-state analytical solutions. J. Hydrol. 2016, 543, 67-87. [CrossRef]

2. Baker, M.A.; Dahm, C.N.; Valett, H.M. Anoxia, anaerobic metabolism biogeochemistry of the stream water-ground water interface. In Streams and Ground Waters; Academic Press: San Diego, CA, USA, 2000; pp. 259-284.

3. Neumann, R.B.; LaBolle, E.M.; Harvey, C.F. The Effects of Dual-Domain Mass Transfer on the Tritium-Helium-3 Dating Method. Environ. Sci. Technol. 2008, 42, 4837-4843. [CrossRef]

4. Zwart, J.A.; Sebestyen, S.D.; Solomon, C.T.; Jones, S.E. The influence of hydrologic residence time on lake carbon cycling dynamics following extreme precipitation events. Ecosystems 2017, 20, 1000-1014. [CrossRef]

5. Hein, T.; Baranyi, C.; Heiler, G.; Holarek, C.; Riedler, P.; Schiemer, F. Hydrology as a major factor determining plankton development in two floodplain segments and the River Danube, Austria. Large Rivers 1999, 11, 439-452. [CrossRef]

6. León, J.G.; Beamud, S.G.; Temporetti, P.F.; Atencio, A.G.; Diaz, M.M.; Pedrozo, F.L. Stratification and residence time as factors controlling the seasonal variation and the vertical distribution of chlorophyll- $a$ in a subtropical irrigation reservoir. Int. Rev. Hydrobiol. 2016, 101, 36-47. [CrossRef]

7. Stumpner, E.B.; Bergamaschi, B.A.; Kraus, T.E.; Parker, A.E.; Wilkerson, F.P.; Downing, B.D.; Dugdale, R.C.; Murrell, M.C.; Carpenter, K.D.; Orlando, J.L.; et al. Spatial variability of phytoplankton in a shallow tidal freshwater system reveals complex controls on abundance and community structure. Sci. Total Environ. 2020, 700, 134392. [CrossRef] [PubMed]

8. Worldometers. Coronavirus Updates. Available online: https://www.worldometers.info/ (accessed on 3 May 2020).

9. ESA COVID-19: Nitrogen Dioxide over China. Available online: https://www.esa.int/Applications/ Observing_the_Earth/Copernicus/Sentinel-5P/COVID-19_nitrogen_dioxide_over_China (accessed on 17 April 2020).

10. Yunus, A.P.; Masago, Y.; Hijioka, Y. COVID-19 and surface water quality: Improved lake water quality during the lockdown. Sci. Total Environ. 2020, 731, 139012. [CrossRef]

11. O'Reilly, J.E.; Maritorena, S.; Mitchell, B.G.; Siegel, D.A.; Carder, K.L.; Garver, S.A.; Kahru, M.; McClain, C. Ocean color chlorophyll algorithms for SeaWiFS. J. Geophys. Res. Oceans 1998, 103, 24937-24953. [CrossRef]

12. Nukapothula, S.; Chen, C.; Yunus, A.P.; Wu, J. Satellite-based observations of intense chlorophyll- $a$ bloom in response of cold core eddy formation: A study in the Arabian Sea, Southwest Coast of India. Reg. Stud. Mar. Sci. 2018, 24, 303-310. [CrossRef]

13. Gao, K.; Xu, J.; Gao, G.; Li, Y.; Hutchins, D.A.; Huang, B.; Wang, L.; Zheng, Y.; Jin, P.; Cai, X.; et al. Rising $\mathrm{CO}_{2}$ and increased light exposure synergistically reduce marine primary productivity. Nat. Clim. Change 2012, 2, 519-523. [CrossRef]

14. Hu, C.; Lee, Z.; Franz, B. Chlorophyll $a$ algorithms for oligotrophic oceans: A novel approach based on three-band reflectance difference. J. Geophys. Res. Oceans 2012, 117. [CrossRef]

15. Scofield, A.E.; Watkins, J.M.; Osantowski, E.; Rudstam, L.G. Deep chlorophyll maxima across a trophic state gradient: A case study in the Laurentian Great Lakes. Limnol. Oceanogr. 2020. [CrossRef]

16. Castelao, R.M.; Mavor, T.P.; Barth, J.A.; Breaker, L.C. Sea surface temperature fronts in the California Current System from geostationary satellite observations. J. Geophys. Res. Oceans 2006, 111. [CrossRef]

17. Atique, U.; An, K.-G. Landscape heterogeneity impacts water chemistry, nutrient regime, organic matter and chlorophyll dynamics in agricultural reservoirs. Ecol. Indic. 2020, 110, 105813. [CrossRef]

18. Sruthy, S.; Ramasamy, E. Microplastic pollution in Vembanad Lake, Kerala, India: The first report of microplastics in lake and estuarine sediments in India. Environ. Pollut. 2017, 222, 315-322. [CrossRef]

19. Zhu, S.; Yang, G.; Dai, J. Sediment Management in East Lake, China: A Combined Bio-Physical and Socioeconomic Approach for Managing Sediments in a Polluted Lake System. Pol. J. Environ. Stud. 2018, 27, 1891-1900. [CrossRef]

20. Dickman, M. Some Effects of Lake Renewal on Phytoplankton Productivity and Species Composition 1. Limnol. Oceanogr. 1969, 14, 660-666. [CrossRef] 
21. Gomes, L.; Miranda, L. Hydrologic and climatic regimes limit phytoplankton biomass in reservoirs of the Upper Paraná River Basin, Brazil. Hydrobiologia 2001, 457, 205-214. [CrossRef]

22. Lee, S.; Lee, S.; Kim, S.H.; Park, H.; Park, S.; Yum, K. Examination of critical factors related to summer Chlorophyll $a$ concentration in the Sueo Dam Reservoir, Republic of Korea. Environ. Eng. Sci. 2012, 29, 502-510. [CrossRef]

23. Wan, Y.; Qiu, C.; Doering, P.; Ashton, M.; Sun, D.; Coley, T. Modeling residence time with a three-dimensional hydrodynamic model: Linkage with Chlorophyll $a$ in a subtropical estuary. Ecol. Model. 2013, 268, 93-102. [CrossRef]

24. Liu, W.-C.; Chen, W.-B.; Kuo, J.-T.; Wu, C. Numerical determination of residence time and age in a partially mixed estuary using three-dimensional hydrodynamic model. Cont. Shelf Res. 2008, 28, 1068-1088. [CrossRef]

25. Vanhellemont, Q.; Ruddick, K. Atmospheric correction of metre-scale optical satellite data for inland and coastal water applications. Remote Sens. Environ. 2018, 216, 586-597. [CrossRef]

26. Vanhellemont, $Q$. Adaptation of the dark spectrum fitting atmospheric correction for aquatic applications of the Landsat and Sentinel-2 archives. Remote Sens. Environ. 2019, 225, 175-192. [CrossRef]

27. Caballero, I.; Stumpf, R.P. Retrieval of nearshore bathymetry from Sentinel-2A and 2B satellites in South Florida coastal waters. Estuar. Coast. Shelf Sci. 2019, 226, 106277. [CrossRef]

28. Pahlevan, N.; Roger, J.-C.; Ahmad, Z. Revisiting short-wave-infrared (SWIR) bands for atmospheric correction in coastal waters. Opt. Exp. 2017, 25, 6015-6035. [CrossRef]

29. Clark, D.K.; Baker, E.T.; Strong, A.E. Upwelled spectral radiance distribution in relation to particulate matter in sea water. Bound. Layer Meteorol. 1980, 18, 287-298. [CrossRef]

30. Gordon, H.R.; Clark, D.K. Remote sensing optical properties of a stratified ocean: An improved interpretation. App. Opt. 1980, 19, 3428-3430. [CrossRef]

31. McKee, D.; Cunningham, A.; Dudek, A. Optical water type discrimination and tuning remote sensing band-ratio algorithms: Application to retrieval of chlorophyll and Kd (490) in the Irish and Celtic Seas. Estuar. Coast. Shelf Sci. 2007, 73, 827-834. [CrossRef]

32. Bowers, D.G.; Harker, G.E.L.; Stephan, B. Absorption spectra of inorganic particles in the Irish Sea and their relevance to remote sensing of chlorophyll. Int. J. Remote Sens. 1996, 17, 2449-2460. [CrossRef]

33. O’Reilly, J.E.; Maritorena, S.; Siegel, D.A.; O’Brien, M.C.; Toole, D.; Mitchell, B.G.; Kahru, M.; Chavez, F.P.; Strutton, P.; Cota, G.F.; et al. Ocean color chlorophyll $a$ algorithms for SeaWiFS, OC2, and OC4: Version 4. In SeaWiFS Postlaunch Calibration and Validation Analyses; NASA Center for AeroSpace Information: Hanover, MD, USA, 2000; Volume 3, pp. 9-23.

34. Jena, B. The effect of phytoplankton pigment composition and packaging on the retrieval of chlorophyll- $a$ concentration from satellite observations in the Southern Ocean. Int. J. Remote Sens. 2017, 38, 3763-3784. [CrossRef]

35. Nagamani, P.; Hussain, M.; Choudhury, S.; Panda, C.; Sanghamitra, P.; Kar, R.; Das, A.; Ramana, I.; Rao, K. Validation of chlorophyll- $a$ algorithms in the coastal waters of Bay of Bengal initial validation results from OCM-2. J. Ind. Soc. Remote Sens. 2013, 41, 117-125. [CrossRef]

36. O'Reilly, J.E.; Werdell, P.J. Chlorophyll algorithms for ocean color sensors-OC4, OC5 \& OC6. Remote Sens. Environ. 2019, 229, 32-47.

37. Witter, D.L.; Ortiz, J.D.; Palm, S.; Heath, R.T.; Budd, J.W. Assessing the application of SeaWiFS ocean color algorithms to Lake Erie. J. Gt. Lakes Res. 2009, 35, 361-370. [CrossRef]

38. Yunus, A.P.; Dou, J.; Sravanthi, N. Remote sensing of chlorophyll- $a$ as a measure of red tide in Tokyo Bay using hotspot analysis. Remote Sens. Appl. Soc. Environ. 2015, 2, 11-25. [CrossRef]

39. Pahlevan, N.; Smith, B.; Schalles, J.; Binding, C.; Cao, Z.; Ma, R.; Alikas, K.; Kangro, K.; Gurlin, D.; Hà, N.; et al. Seamless retrievals of chlorophyll- $a$ from Sentinel-2 (MSI) and Sentinel-3 (OLCI) in inland and coastal waters: A machine-learning approach. Remote Sens. Environ. 2020, 240, 111604. [CrossRef]

40. Winarso, G.; Marini, Y. MODIS standard (OC3) chlorophyll- $a$ algorithm evaluation in Indonesian seas. Int. J. Remote Sens. Earth Sci. 2017, 11, 11-20. [CrossRef]

41. Reynolds, C.S. The Ecology of Phytoplankton; Cambridge University Press: Cambridge, UK, 2006. 
42. May, C.L.; Koseff, J.R.; Lucas, L.V.; Cloern, J.E.; Schoellhamer, D.H. Effects of spatial and temporal variability of turbidity on phytoplankton blooms. Mar. Ecol. Prog. Ser. 2003, 254, 111-128. [CrossRef]

43. Bennion, D.H.; Warner, D.M.; Esselman, P.C.; Hobson, B.; Kieft, B. A comparison of chlorophyll $a$ values obtained from an autonomous underwater vehicle to satellite-based measures for Lake Michigan. J. Gt. Lakes Res. 2019, 45, 726-734. [CrossRef]

(C) 2020 by the authors. Licensee MDPI, Basel, Switzerland. This article is an open access article distributed under the terms and conditions of the Creative Commons Attribution (CC BY) license (http://creativecommons.org/licenses/by/4.0/). 